\title{
Alerta en el bosque mesófilo de montaña veracruzano
}

\author{
M. A. Espinoza-Guzmán² - S. Prieto³ - C. R. Cerdán - M. Paéz² - G. C. Ortiz¹
}

\section{RESUMEN}

El desarrollo de actividades humanas dentro del Bosque Mesófilo de Montaña causa serias amenazas de importancia ambiental y económica que tiene este ecosistema en Veracruz. Esta nota presenta una estimación del área de bosque que se ha perdido a lo largo de 17 años, trabajo que se ha realizado con ayuda de imágenes satelitales de 1999, 2010 y 2016. La principal causa de pérdida de bosque es el cambio de uso de suelo hacia áreas de infraestructura.

\begin{abstract}
Human activities in tropical montane cloud forests cause serious threats to its environmental and economic importance in Veracruz. This note reports an estimate of how much cloud forest area has been lost over 17 years, research that has been done with the help of satellite images from 1999, 2010, and 2016. The main cause of cloud forest loss is land use change to infrastruc-

ture areas.
\end{abstract}

Palabras Clave: bosque mesófilo, cambio de uso de suelo, cafeticultura, cuenca La Antigua, imágenes satelitales.

Keywords: coffee cultivation, La Antigua watershed, land-use change, satellite images, tropical montane cloud forests.

E 1 bosque mesófilo de montaña (BMM) o bosque de niebla, es un ensamble de diversas especies de plantas y animales que cohabitan en las zonas montañosas templadas y húmedas como las que se observan en las proximidades de las ciudades veracruzanas de Xalapa, Banderilla, Naolinco y Miahuatlán, por citar algunas. Estas zonas, además de la alta diversidad biológica que conservan, presentan condiciones que favorecen la infiltración de agua de lluvia y neblina, que es recibida por el suelo para infiltrarse y mantener la recarga del manto freático y posteriormente extraerla, ser canalizada y llevada a las ciudades, pueblos y comunidades humanas.

Las áreas con BMM son de importancia paisajística para quienes los habitan, de impor- tancia de habitat para organismos silvestres $y$, también, proveedores de servicios ambientales (como la generación y provisión de agua) para quienes viven cuenca abajo. Sin embargo, todas estas funciones están seriamente amenazadas directa e indirectamente por las actividades humanas que se desarrollan en él y en sus proximidades.

Por lo anterior, los integrantes de los Cuerpos Académicos «Agroforestería y Silvicultura Sustentable» y «Calidad Ambiental» de la Universidad Veracruzana, así como del Observatorio de la Cafeticultura Veracruzana, se propusieron monitorear los cambios que ha tenido este ecosistema en la cuenca del río Actopan, Veracruz en los años de 1999, 2010 y 2016. Lo anterior con base en procesos geoestadísticos

1 Cuerpo Académico «Agroforestería y Silvicultura Sustentable», Facultad de Biología región Xalapa. Universidad Veracruzana.

2 Cuerpo Académico «Calidad Ambiental», Facultad de Biología región Xalapa. Universidad Veracruzana.

3 Alumno, Facultad de Biología región Xalapa. Universidad Veracruzana.

*Autor para correspondencia: maespinoza@uv.mx 
y de interpretación de imágenes satelitales LANDSAT, es decir en función del color de pixeles y datos verificables en campo dentro de la cuenca. De esta manera permitió estimar las superficies del bosque mesófilo en 17 años. La superficie con BMM fue identificada en cada periodo de estudio a través de la interpretación de uso de suelo y vegetación con base en colores (firmas espectrales).

Durante el desarrollo de la investigación se calculó que la superficie de toda la cuenca del río Actopan es de 204116 hectáreas (Fig. 1) que incluyen, parcialmente o totalmente, los municipios de Acajete, Acatlán, Actopan, Alto Lucero, Apazapan, Banderilla, Coacoatzintla, Coatepec, Chiconquiaco, Emiliano Zapata, Xalapa, Jilotepec, Juchique de Ferrer, La Antigua, Landero y Coss, Miahuatlán, Naolinco, Puente Nacional, Las Vigas, Rafael Lucio, Tatatila, Tepetlan, Tlacolulan, Tlalnelhuayocan,
Tonayán y Úrsulo Galván. Con los resultados obtenidos mediante la interpretación de imágenes de satélite, se estimó que en el año de 1999 en la cuenca del río Actopan disponía de 26891.92 ha de bosque mesófilo de montaña, lo que representa el 13.2\% del total de superficie de la cuenca (Fig. 1), y 11 años después (2010), se estimó que disminuyó a 20418.3 ha (10.0% del total de la cuenca). Esto indica que en el periodo de 1999 a 2010 la disminución fue del 24.1\%.

Para 2016, se identificó que éste ecosistema abarcaba 14208.6 ha (7.0 \% del total de la cuenca). Esto indica que en un periodo de 17 años de 1999 a 2016 se perdieron 12689.3 hectáreas de BMM dentro de la Cuenca, lo que representa la reducción de 47.2\%. Las hectáreas perdidas se han convertido principalmente a áreas urbanas. En algunas lugares, sobre todo de menor altitud, el BMM también están cambiando hacia la siembra de cítricos y caña de azúcar.

\section{Figura 1. Distribución del bosque mesófilo de montaña en la cuenca del río Actopan, Ver.}
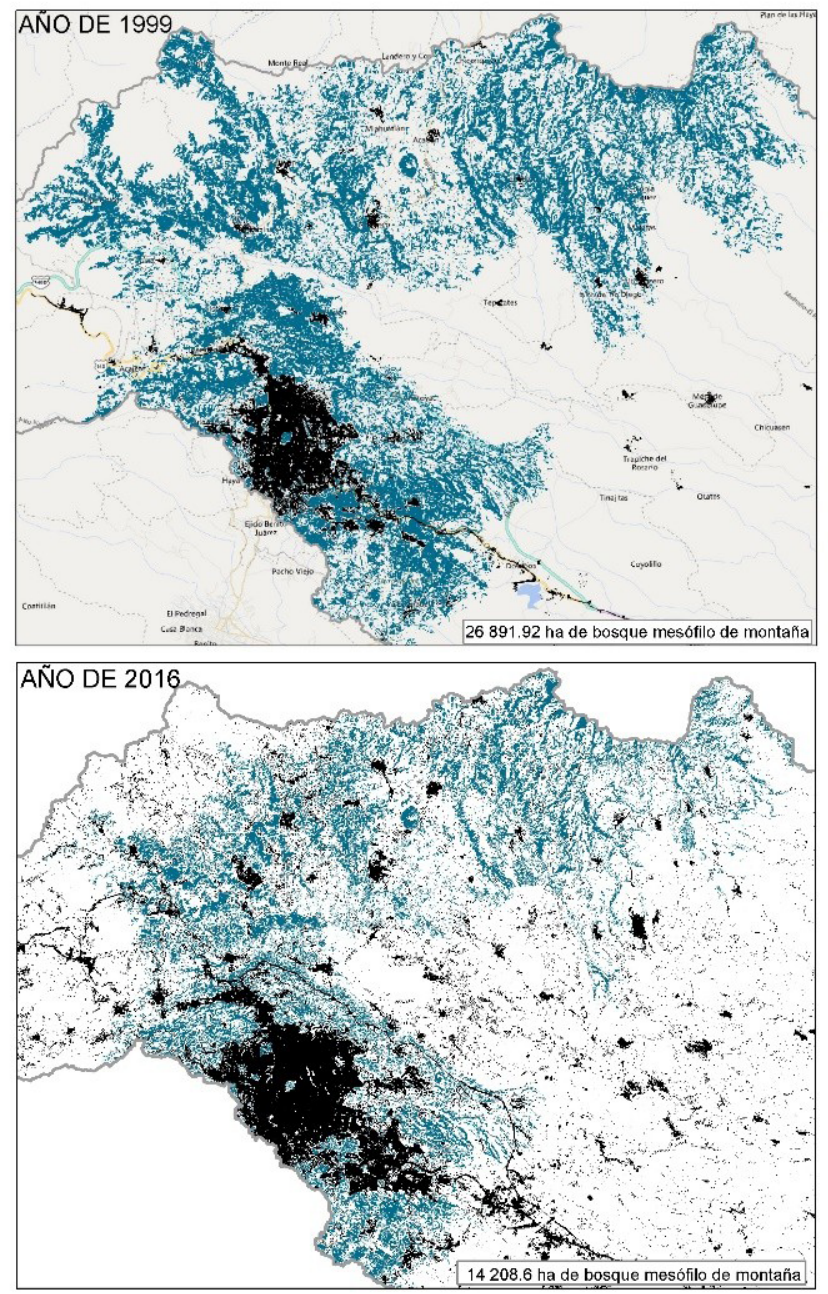
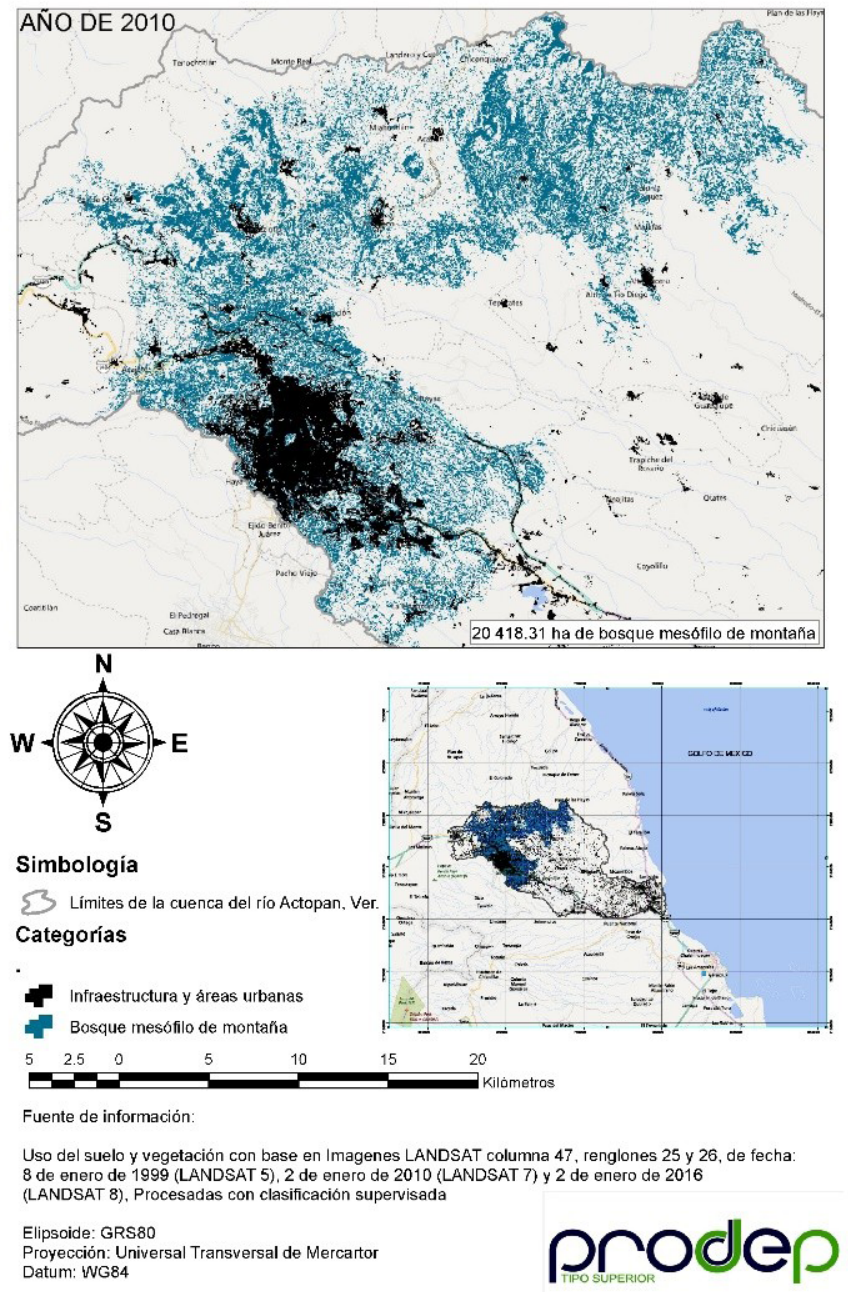
Lo anterior es relevante para encender alertas sobre las circunstancias que enfrenta el bosque de niebla. Debemos recordar que este ecosistema es vital para la zona por los millones de litros de agua que infiltra y almacena, las toneladas de carbono que almacena, su capacidad regulando el clima, así como por ser el hogar de múltiples especies de flora y fauna, incluyendo especies migratorias que se trasladan cientos de kilómetros hacia este ecosistema.

Se hace necesario como opción productiva el conservar los sistemas agroforestales cafetaleros. Muchos relictos de BMM están circundados por cafetales, los cuales, debido a su cobertura arbórea, pueden parcialmente disminuir la presión que recae sobre el BMM. Sin embargo, los sistemas agroforestales cafetaleros también están cambiando hacia urbanizaciones, sobre todo los cercanos a las áreas urbanas.

Considerando el cambio de uso de suelo, la pérdida de superficie de Bosque Mesófilo de Montaña, así como de sistemas agroforestales cafetaleros, se hace necesaria una mayor protección. Si bien la cafeticultura no contribuye a nivel ecosistémico de la misma forma que el BMM, si es una actividad productiva que le quita presión, sobre todo cuando su cobertura arbórea es diversa y compleja. Un ordenamiento territorial participativo e incluyente, como el marco legal nacional lo exige, se hace necesario para lograr la conservación de este importante ecosistema. 